\title{
THE ROLE OF SYSTEMS THEORY IN POLITICAL SCIENCE: THE CASE OF UNEMPLOYMENT IN SPAIN
}

\author{
Author(s) / Auteur(s) : \\ Francisco Parra-Luna, \\ Emeritus Professor, Universidad Complutense de Madrid \\ Parraluna3495@yhoo.es
}

\begin{abstract}
Résumé :
This paper will be consecrated to the problem of unemployment in Spain from the perspective of Systems Theory. But first I would like to emphasize, in a very schematic form, some of the possibilities and advantages of Systems Theory in Political Science. The purpose is only to suggest that the application of some theoretical and methodological principles of Systems Theory could contribute significantly to the development and efficiency of political systems. Let us say for the moment that the endevour requires to fulfill two main prerequisites: first to adopt the basic systemic principle which is to select the essential variables for any given piece of research within a polity; and second, to discover the "system of values" that underlines this polity. To ignore these two fundamental prerequisites should be in principle theoretical and methodologically criticized as we hope to show when we study the unemployment problem in Spain. The application of the model could reduce unemployment from the current 17,1\% until some $12 \%$ in the period of 4 years.
\end{abstract}

Keywords / Mots-clés :

unemployment; Axiological model; system of values; job creation; taxes reform

\section{INTRODUCTION}

To start, five main contributions of Systems Theory could be available for political scientists: a) A new modeling of political systems explaining their more relevant variables; $b$ ) The definition of polities as transforming entities which convert "Inputs" into "outputs" and where the relationship "outputs/inputs" is essential for the citizen; c) a Soft Systems Methodology for the understanding of complexities; d) An operational way able to defines the important concepts like social and political change, progress, ethical behavior, and others. e) A cybernetics approache to analyze/criticize the regulations of political systems in their financial, economic, labor, judicial and others dimensions; f) And above all the definition and measurement of political efficiency with empirical applications to the Nation-State, local political systems, and other public organizations.

For this purpose, let me close this brief introduction by presenting only a selected sample of publications of the author. The reader can see 27 of these hypotheses or possibilities for organizations in general in "An Axiological Systems Theory: Some Basic Hypotheses"(1), an empirical measurement of the organizational efficiency: in "A Score Card for Ethical Decision Making" (2), and a measure of the efficiency of political systems in "Could we speak of a Social Sin of Political Science?: an application of Axiological Systems Theory, (3) Let me then leave open this discussion for the moment and let go towards the problem of unemployment in Spain. 


\section{UNEMPLOYMENT IN SPAIN: THE AXIOLOGICAL-SETCU MODEL}

Consequently, this paper will be devoted from now to describe the so called "AxiologicalSETCU model to reduce unemployment in Spain. This problem is so acute $(17,1 \%$ of active population) in comparison with other European countries, that it seems clear that only through a systemic epistemological approach (what I call "Axiological Systems Theory") the problem could be solved.

It is accepted that complex phenomena, like the actual unemployment level, cannot be understood by only economic specialized colleagues, but through some interdisciplinary and multi-ideological teams of experts that at the same time use an integrative methodology like f.i. the derivate of General Systems Theory. In this line it is necessary to establish some necessary methodological requirements.

The first one is to define an "International Comparable Space" (ICS) useful to place Spain among a set of countries where comparatively should be. It is clear that nothing is big or small, beautiful or ugly, but in comparison with others. Therefore, Spain needs to be compared with some other countries which are similar attending geography, history and culture, and at the same time could be considered as the "mirror" in which to look. I suggest that an ICS for Spain could be shaped by: Germany, France, United Kingdom, Italy, Netherlands, Belgium, Sweden, Austria, Denmark and Finland. This set of countries could be a valid reference for scientific comparisons (it does not matter which position correspond to Spain) instead of using selected countries in order to justify some expected or desired results. This is a bias which unfortunately abound.

Let us explicit that the Spanish economy presents, maybe in the four more basic indicators of a national economy, the following unbalanced results in September 2011 (4):

1. The highest level of unemployment (17,1 \% of active population)

2. A positive level of commercial deficit ( $1,4 \% \mathrm{GNP})$

3. The highest level of economic growth (3,1 of GNP)

4. A lower level of inflation (2\%)

Why the Spanish economy is in such unbalanced state in comparison with the ICS countries?. According to some postulates of Systems Theory because the Spanish government would be committing the following four methodological mistakes; first, to ignore the "systems of values" underlines Spanish society; second, to ignore therefore the three main axiological disequilibria of Spanish economy; third, to present some partial solutions without calculating them in an integrated model; and fourth, to apply only some obsolete and routine economic theories. One thing is clear: the level of unemployment in the main European countries is in October 2017: Austria 5,6; Belgium 7,3; France 9,8; Germany 3,6; Italy 11,2; Netherlands 5,9; Denmark 4,5 and Sweden 6,0; the average is 6,8, less than the half of Spain. Why this difference happen in this indicator and not in the other three? 


\section{Against the first mistake: To start analyzing the Spanish "system of values".}

From a humanistic perspective nothing seems more important than to know in which "System of Values" we live. But this knowledge needs a brief explanation on the origins of the axiological method. And for that it is necessary to remember the theory of human needs, especially when the anthropologist C. Kluckhohn(5) sustains that "values" is the reverse of the medal of need." A theory of needs that starts with the natural low (Aristoteles and Ciceron), continues with Tomas de Aquino and Francisco Suarez during XIII century, until the modern Axiology (the science of the good and valuable) with Ehrenfels, Meining and Bretano, followed by Max Scheler and Robert S. Hartman among others, and becomes official with the ONU Universal Declaration of Human Rights in 1948. After, several social sciences have completed the set of universal needs like f.i., Maslow en Psychology, Laswell and Deusth in Political Science, Bauer and Gross in Sociology, Rawls in Philosophy and more recently Doyal and Gough (6), Heller (7), Mendez (8) and Max-Neef (9) and myself, Parra-Luna (10), among others.

Specifically, the list of universal values I am using as a general model is the following:

Table 1: A Reference Pattern of Universal Values (RPUV)

\section{Values}

Health

Wealth

Security

Knowledge

Freedom

Distributive Justice

Nature Conservation

Quality of Activities

Moral prestige

\section{First empirical indicator}

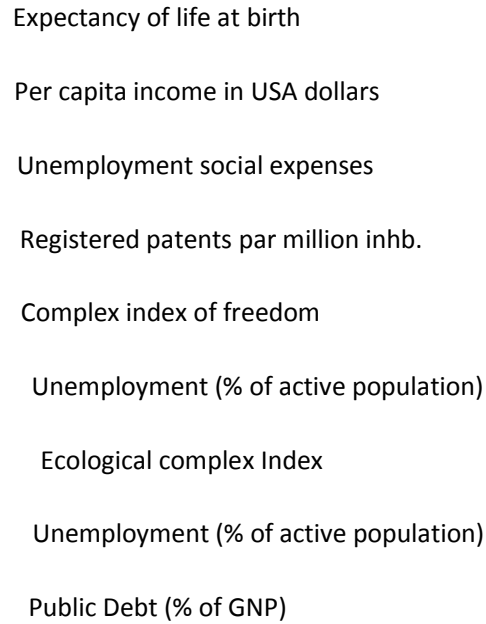

This list have two main characteristics: first, it should be accepted as a closed model where all possible human needs, (in any space or time in the world) are included: and second, these nine couples of "needs/values" are dialectically interrelated in such a form that when one of them is modified, the rest are also modified in several and dynamic degrees and in a positive or a negative way. This will be the Reference Pattern of Universal Values (RPUV) that will be used in this work through the integration of the two principles: systemic and axiological.

Let us see the Spanish position according to the available data. For doing that all the data will be placed within un standardized interval of variation (f.i. $0-100$ ), corresponding " 100 " to the country with the best position, and the level " 0 " the country with the worse position. The rest of the countries will be situated proportionally between these two extremes. 
Therefore, in the value HEALTH (H) (Fig. 1) corresponds the level of "100" to France $(80,98$ years of life expectancy) and " 0 " to Denmark (78,30 years) and where Spain has a relatively high position (80,05 years). For the value WEALTH correspond " 100 " to Holland (40.718 USA dollars per capita) and with Italy in the lower position "0" (31.909 USA \$) and where Spain has also a very low position (32.545 USA \$). In this way we can place the other seven values and their respective indicators in order to form the axiological profile of fig. 1.

Fig. 1: The Spanish Axiological profile



Where: S=Health: RM=Wealth; Se=Security; L=Freedom; JD=Distributive Justice;

$\mathrm{CN}=$ Conservation of the Nature; $\mathrm{CA}=$ Quality of Activities; and PM=Moral Progress

Limiting for the moment the operational definition of this RPUV to only one indicator, the position of Spain is shown through the non-equilibrated or unbalanced axiological profile of fig. 1, contrasting to the average of the ten countries in the ICS. What should be done according to this profile?. As a general rule the profile should first be "horizontalised" and second "elevated". It means that the best possible policy is to increase the area under the profile (the space between the profile and the abcisas exe). It seems clear that the extreme position of Spain in the profile advises to increase the values of WEALTH, KNOWLEDGE, DISTRIBUTIVE JUSTICE AND QUALITY OF ACTIVITIES, even at the cost of lowing the values of SECURITY (reducing unemployment expenses) and MORAL PRESTIGE (increasing the Public Debt). All that means that the correct question is not: What kind of economy have we?, but to ask "what kind of society have we?". This is the crux of the problem.

From this knowledge it is secondary if the economy is going to growth in form of $\mathrm{L}, \mathrm{V}, \mathrm{U}$ or 140 
W, because what is essential is to know towards we are going in terms of our "System of Values". What does then this imbalance mean?.

First, we face a Methodological problem. Because the explanatory variables are not the banks, the public debt, the growth of the GNP, the rate of inflation or the commercial deficit. The variables that explain the state of our unemployment are the unbalance between the values persecuted and the values realized. For instance, our permissiveness towards the regulations and controls which made possible in Spain some financial scandalous like those of: ForumAfinsa, Gurtel, Palau, CAM, Punica, Canal, etc. or bonus millionaires for the bank directors who precisely did not fulfill with their duties.

These considerations should change the basic relationship between "unemployment" an "economic growth". Today we use the formal expression: Employment=f(economic growth) without realizing that even if we growth to a rate of 3\% PIB per year, we would not reduce real unemployment. Because what is true is precisely the inverse, that is: Economic growth=f(employment), what makes that the independent explanatory variable is the creation of jobs, and considering now full time jobs.

Against the second mistake: To show the specific differences of Spanish economy to International markets and financial organizations.

A first analysis of our axiological profile shows 36 desequilibria o unbalances in our "system of values" which can be summarized into three:

a) Spain, due to its traditional commercial deficit because of its low economic competitiveness, needs a big amount of technological and other structural jobs. See table 2 where there is a first inventory of potential jobs estimated by some Spanish organizations:

Table 2: Potential jobs in Spain

TOTAL POTENCIAL JOBS FOR SPAIN AT THE END OF THE PERIOD (2017-20) (OPTIMUN POSSIBILITIES)

*Transports infrastructures

*Chamartin Plann

$* 1+D+1$

*Communications techonologies

*Renovables energies

*House construction

*House rehabilitation

*Hospitals

*Nurses

* Care of dependents

* Day care centers for children

*Forest conservation and explotation
240.000

60.000

222.000

200.000

72.000

108.000

500.000

350.000

150.000

50.000

250.000

250.000 


\begin{tabular}{|cc|}
\hline *Development of the nautical & 200.000 \\
*Inspectors, judges, police.. & 60.000 \\
*Autonomous entrepreneurs.... & 700.000 \\
*European service directive & 200.000 \\
*Water treatment & 380.000 \\
Total & 4.152 .000 \\
\end{tabular}

b) Also, Spain has more than un $17 \%$ of active population unemployed, and most of them are under 44 years old, where the $42 \%$ of the these unemployed has an acceptable formation ( $42 \%$ university studies ; $36 \%$ basic studies and only $22 \%$ do not have studies at all). It thus means that there is a big non applied potential employment in Spain (11) for the most educated who are unemployed.

c) The third characteristic is that Spain makes a lot of unnecessary expenses in times of


of unemployed for doing nothing, which is socially just, and even politically advisable, but it is a big irrationality from an organization point of view. There are also huge public expenses due to the political autonomous systems and all the public organisms and enterprises that they sustain.

Summarizing the 36 unbalances, table 3 presents the three big (Unemployment, Needs and

Table 3: The three main unbalances in the Spanish economy

\section{THE THREE MAIN UNBALANCES OF SPANISH ECONOMY}

1. NEEDS

(4.152 .000 potential jobs)

2. UNEMPLOYMENT (3,9 millions)

3. AVAILABLE FINANCIAL MEANS ( 36.000 millions euros per year)

*Less unemployment expenses

20.000

*Decrease of Fiscal Fraud

*Less public expenses

2.000

*Private collaboration

6.000

These three possibilities are not applied in Spain, which could explain the difference on unemployment in relation with the ICS countries. 
Financial possibilities) at such levels that are quite unknown in the world. Therefore the following question cannot be avoided: How is it possible that we allow at the same time, to have $17 \%$ unemployment, more than 4 millions of vacant jobs, and to through away more than 36.000 millions euros per year?. How politicians, technicians and people in general, support such untenable situation?. A second question is also unavoidable: Could be powerful personal interests in maintaining in Spain such a high level of unemployment?. Could it favor low salaries and other labor abuses?. We do not know, but the statistical numbers are there. Fig. 2 try to illustrate the possibilities of this unbalanced situation.

Fig.2: The disconnection among imbalances in Spain

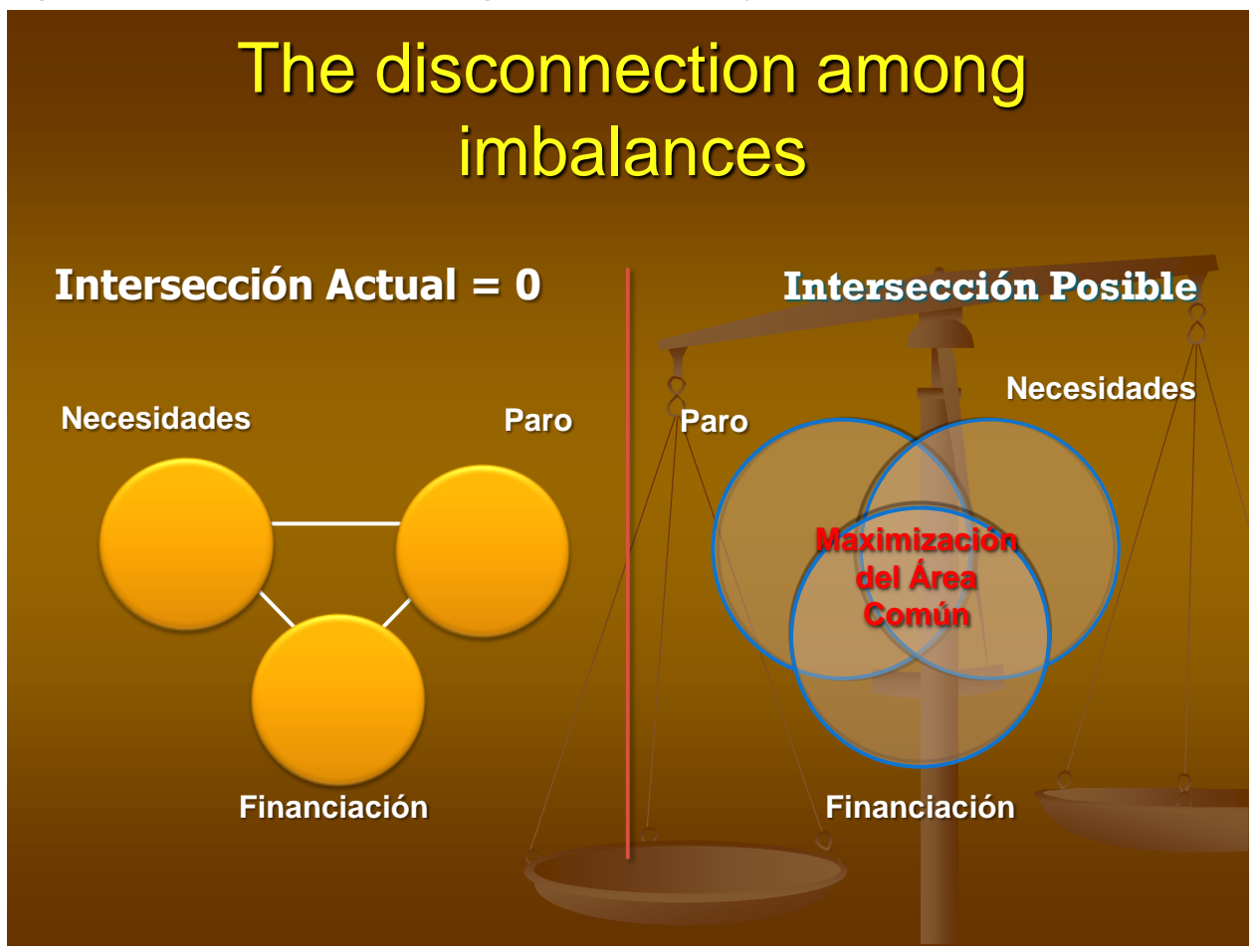

Where:

Necesidades $=$ Needs

Paro=Unemployment

Against the third mistake: To build a systemic-quantitative model on the base of these three unbalances

Let us start with four considerations:

a) Once the essential problem has been commented, let us start with the secondary one, that is, the calculations performed, always provisional and subjected to a deep revision. We know that in front of this level of unemployment we have two main ways to overcome it: one is to decrease public expenses in order to reduce fiscal deficit and 
public debt; the other is to try to growth economically in order to reduce deficit through fiscal incomes. The first possibility does not reduce enough real unemployment, but it is the way recommended by the international institutions dealing with the problem; the second way makes the country richer by increasing employment, but it reduces fiscal deficit slower, needs to adopt some new theoretical and methodological approaches, and demands more personal efforts and important changes of attitude. Fig. 3 shows in Spanish the mathematical structure of the Axiological-SETCU model:

Fig. 3: The simplified formal structure of the Axiological model

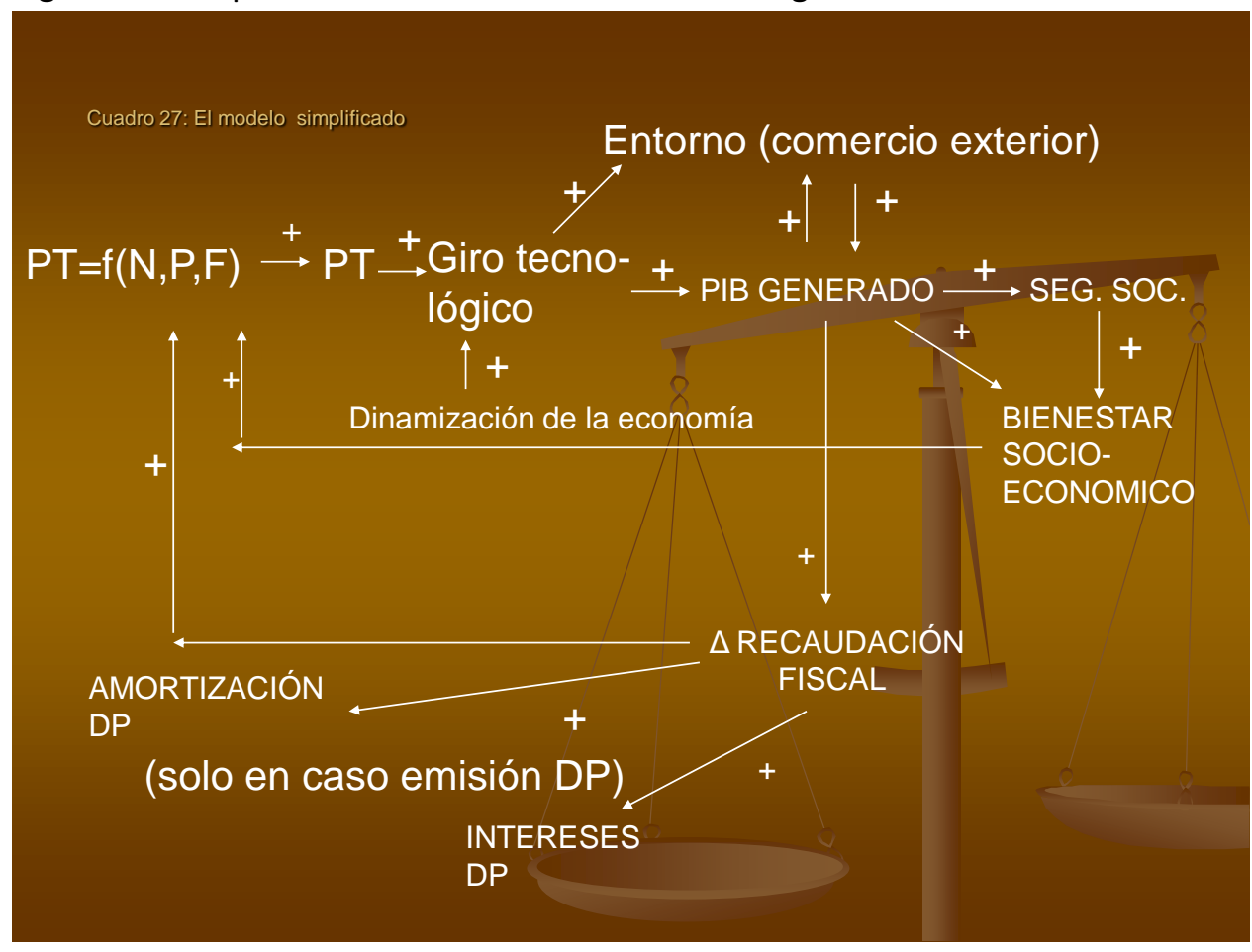

$\mathrm{PT}=$ puestos de trabajo $=\mathrm{JOBS}$

$\mathrm{N}=$ necesidades $=$ NEEDS

$\mathrm{P}=\mathrm{ParO}=\mathrm{UNEMPLOYMENT}$

Giro tecnológico=TECHNOOOGICAL CHANGE

PIB GENERADO=INCREASE OF GNP

Entorno (comercio exterior)=ENVIRONMENT (FOREING TRADE

SEG.SOC.=SOCIAL SECURITY

BIENESTAR SOCIOECONÓMIOCO=SOCIOECONOMIC WELLNESS

Dinamización de la economía=DINAMISATION OF THE ECONOMY

RECAUDACIÓN FISCAL=FISCAL COLLECTION

INTERESES DEUDA PÚBLICA=INTERESTS FOR THE PUBLIC DEBT

AMORTIZACION=AMORTIZATION OF THE DEBT 
which has been simplified in order to show clearly its possibilities. The operational model has only 19 variables and 35 simple linear equations. They are represented by $\mathrm{PT}=$ "Puestos de trabajo" due to the necessary inter-connection between $\mathrm{N}=\mathrm{Needs}$, $\mathrm{P}=\mathrm{Paro}$ (unemployment) and $\mathrm{F}=\mathrm{Financial}$ possibilities, in order to generate the increase of exports, GNP, Fiscal incomes and the rest of social and economic advantages derived. Then, through a simple Excell program. The model was circulated four times (one for each year) so that the results of the first year accumulates the possibilities of the second year and so on. Useless to say that the important issue is the method, not the accuracy of the calculations. As $\mathrm{H}$. Simon used to say: we will have time to add complexities.

b) The simulations

On the base of this formal structure, nine simulations were realized changing certain parameters in the model (salaries, private finances, rate of interest, public debt, etc.), but their results were not significantly different. According these simulations the most probable result was: Unemployed 3,914 millions, less 1,289 new jobs $=2,625$ as the new unemployed. Therefore $2,625 / 22,7$ the active population $=11,6 \%$, or $12 \%$ in round figures.

c) Is it the model realistic?

When a given theoretical model anticipates an unexpected positive result, the criticism is well known: "the sheet of paper permits everything". But as it can be seen in table 5, there are at least four possibilities or degrees of ambition in the model. From these four results the model adopted the fourth one, which forecast 1.287 .000 new jobs, needs 113.025 millions of euros, which come from PD=Prestación por Desempleo (unemployment social expenses); FF=Fraude Fiscal (fiscal fraud and black economy); and AGP=Ahorro Gasto Público (decrease of public expenses).

In order to get these results, it should be necessary that the central government, together with the seventeen Spanish Autonomies, adopt a big and coordinated plan devoted to: a) to decrease those public expenses that are superfluous and not productive; and $b$ ) to invest these savings in the creation of new jobs in productive and high technological sectors. Table 4 shows the results of the model which creates at the 
Table 4: Is the model realistic?

\begin{tabular}{|lccl|}
\hline \multicolumn{4}{|c|}{ POSSIBILISM VERSUS VOLUNTARISM } \\
& Jobs & Investment (ME) & Finantial means \\
Possible maximun & 4.157 .000 & 373.402 & Non applied \\
Estimated maximun & 3.130 .000 & 281.700 & Non applied \\
Basic model (Hip. 1) & 1.950 .000 & 179.932 & UE+FF+PD \\
Realistic model (Hip. 9) & 1.287 .000 & 113.025 & UE+FF +LPE \\
& & & \\
& & & \\
UE=Unemployment expenses & & \\
FF=Fiscal fraud & & & \\
PD=Public debt & & \\
LPE=Less public expenses & & \\
\end{tabular}

end of the fourth year 1.287.000 new jobs which supposes an accumulated PIBA=Producto Interior Bruto Ajustado, ( Adjusted GNP) of 14,36 \% in the four years of the model, that is to say: $14,36 / 4=3,5 \%$ of GNP as the average during the period as figtable 5 shows.

Table 5: Structure of increases of jobs and GNP during the period

\begin{tabular}{|lccccc|}
\hline \multicolumn{7}{c|}{ JOBS ACCUMULATED DURING THE PERIOD $2017-20$} \\
Year & Jobs (thousands) & \%GNP & c & \%AGNP & GNP (Millions Euros) \\
& & & & & \\
2017 & 356 & 1,8 & 0,2 & 0,36 & 3.600 \\
2018 & 825 & 4.1 & 0,8 & 3,28 & 32.800 \\
2019 & 957 & 4,8 & 0,9 & 4,32 & 43.200 \\
2020 & 1287 & 6,4 & 1,0 & 6,40 & 64.000 \\
Totals & 3425 & & & 14,36 & 143.000 \\
\hline
\end{tabular}

The model needs nevertheless a big effort to be implemented. An effort based in two changes: the first one coming from the politicians since both the government and the opposition should arrive to a formal agreement to implement the model. The second change needs a strong collaboration between the bureaucracies of both the central state and the seventeen autonomies. It is then necessary a correspondence between the illness of the situation ( $17 \%$ unemployment) and the grade of effort to be realized, but today this correspondence is still not assumed. In general, both the central state and the autonomies, should devote their efforts to use the monetary mass in 
circulation in the creation of productive technological jobs, making a definitive shift from the "consumptive" towards the "productive". Two examples of these productive investments are: first, the construction of infrastructures for railway transportation of raw materials; and second, scientific research towards electric cars and the necessary new batteries for accumulation of electricity.

d) The complementary reforms.

Four reforms are at least necessary: fiscal, financial, institutional and labor relationships. About the first it needs a global change, as f.i. suggests table 6 , where all the taxes dealing with "productive" process have to been decreased and, on the contrary, taxes to the rest of activities, increased. It would not be necessary to increase the fiscal taxes as a whole, but only to potentiate and help the productive technological processes.

\section{The Systemic Fiscal Reform}

It seems clear that it would be very convenient to modify the Spanish structure of taxes like point table 6 .

Table 6: A possible Tax reform

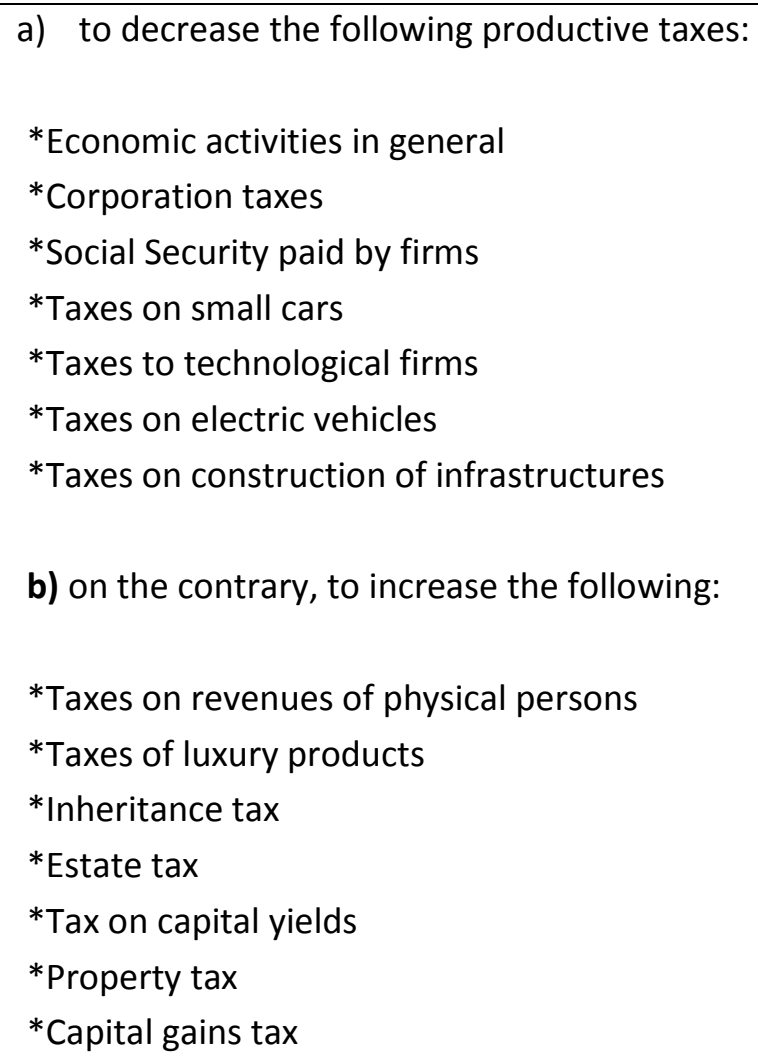

a) to decrease the following productive taxes:

*Economic activities in general

*Corporation taxes

* Social Security paid by firms

*Taxes on small cars

*Taxes to technological firms

*Taxes on electric vehicles

*Taxes on construction of infrastructures

b) on the contrary, to increase the following:

*Taxes on revenues of physical persons

*Taxes of luxury products

*Inheritance tax

*Estate tax

*Tax on capital yields

*Property tax

*Capital gains tax

These modifications of taxes could keep the same tax pressure as the percentage of GNP. 
The second reform, the financial one, should made available credits for projects which are acceptable from the technical and economic points of view through a new official institution like the old ICO (Instituto de Credito Oficial) and even, if necessary, through the nationalization of the bank system.

The third and fourth reforms, the institutional (f.i., to facilitate the creation of enterprises), and the fourth, the labor relationship (to adopt European standards) should also be implemented without a big effort if there is the necessary political will. Other reforms like de Educative and Judicial systems are also necessary but we have not space here to deal with them.

\section{Against the fourth mistake: To supplement current Economic theory with new approaches}

The Axiological-SETCU model was specially designed to generate CONFIDENCE on the possibilities of Spain to overcome the unemployment. The basic requirement is that the model must be technically and politically approved by consensus, and it should forecast positive results for enterprises, workers and population in general. See the necessary theoretical and methodological shift from model A towards model B in fig. 3.

Model $\mathbf{A}$ is very simple. It stats from the unemployment crisis, this is treated by current economists principles following a certain theoretical inertia, which implies also e logical institutional inertia to finish by increasing the economy, but not reducing the scandalous gap of unemployment existing between Spain and the main European countries.

Model B is a little more complicated since it is necessary to go through the axiological theory in order to analyze the "system of values" that Spain is practicing, and then to establish a model which should be systemic, specific for job creation and quantified. Such a model should give sufficient confidence to investors and people in general in order to implement it with positive results.

But to achieve this confidence is only possible if two changes are made: political and technical. The political change is today in Spain absolutely necessary due to the lack of confidence in the Government about reducing real unemployment.

It is not sure that the opposition could do it better, but even so, a change is even urgent.

The technical change is even more necessary because much of the times politicians act according to so called technical advisers, usually economists. But this change is at the same time more difficult to achieve since it would require three changes in the epistemological attitude of economists: first, to be humble enough to recognize the limits of the "economists" approaches and therefore the need to adopt more multi-disciplinary approaches to understand what is really going on in the current employment policy; second, to understand that human beings are always looking for the satisfaction of some needs which only can be satisfied through the production of the corresponding "values" (see Kluckohnn), and thus the need of adopting the study and analysis of political systems through an axiological approach; 
and third, the need to adopt a necessary integrated teams of experts from different ideological premises.

The integration of these three changes could be operationally possible by using systematically some method of inter-subjective agreements among experts like f.i. the Delphi method.

Finally, once the four mistakes described before have been avoided, then it is possible to elaborate and present through all the mass media, an INTEGRATED QUANTITATIVE PLAN, WITH POSITIVE RESULTS FOR THE SPANISH POPULATION, TECHNICALY AND POLITICALLY APPROVED BY CONSENSUS.

This sentence have only sixteen words, but not one less. It seems quite probably that if Spanish government would apply it, the necessary confidence would be achieved.

The big question is: Why the Spanish government does not adopt an strategy like this, so full o common sense?. Is it because the model has been elaborated mainly by sociologits?. Is it because the axiological approach is considered heterodox?. Is it because this method does not sound well to current economists approaches?. Maybe be the answer is because we are not flexible enough to adopt other approaches, or because we thing that it is not possible to do something different. The problems could be then the results of these negative positions in comparison with the results forecasted by the Axiological-SETCU model.

\section{CONCLUSION: SPAIN, A CASE OF PERMITTED UNEMPLOYMENT?}

A country with the axiological profile seen in fig. 1, with the highest level of unemployment; one of the lowest per capita income; and the one that expend more money on unemployment, presents at the same time the solution to its problems. And if the reader has a doubt, please try to avoid the four mistakes done in the Spanish political economy during these two past decades and maybe you will be $\mathrm{n}$ agreement with the Axiological SETCU model.

The solution seems so logical that if it has not been implemented must be because there could be some other hidden intentions around the problem. Let us think f.i. what would happen is tomorrow would appear in the Spanish Official Bulletin a legal norm saying:

"Anyone who perceive the social aid for unemployment will be obliged to do some public works like cleaning the streets of papers, plastics and other dirtiness. For this purposes he/she will be equipped with the necessary means. The receiver will have a salary which will be equivalent to the social aid for unemployment and this salary will have two components: a) fixe, equal to the $20 \%$ of this basic salary; and b) variable, in function of the degree of cleanliness evaluated for an inspector (other unemployed with better education), who at his turn will be evaluated by other unemployed (with a higher level of education)". And so on until to arrive to the responsible of expending the total quantity of unemployment in Spain (some 25.000 millions euros per year). 
This solution is very simple and direct. From this moment may be half of the unemployed would disappear from the statistics, either because half of them accept the job of "ecological worker", or because the other half do not accept to put on working clothes. And there are lots of other public functions which could also be done by the unemployed.

This does not mean that the Axiological-SETCU model proposes to solve the unemployment problem in Spain through this simple solution. Not at all. Spain have many other functions (more techniques and sophisticated) that are expecting to be performed if Spain wants really to develop all its potential. But it is the simplest example.

Therefore, we passed from the zero to Infinitum and from the infinitum to zero. From the $17 \%$ unemployment we passed to see the possibility of reducing it to some European average, but for seeing again that the technical solution represented by the sentence of the sixteen words (see upper) will not be implemented according to some academic and political insights. Why?, which is the explanation?. It seems that it is rather a question of mental flexibility. That is why we want to finish this work mentioning to Paul Krugmnan when he says: "Some people thing that our economic problems are structural and that they have not solution to the short term, but I think that the only structural important obstacle for the prosperity of the world, are the obsoletes doctrines which occupy the heads of men."

\section{CONCLUSION}

According to Systems Theory and the works developed in (1), (2), (3) and (4) what the Spanish employment policy would need is to accomplish the following seven steps:

First: All the measures suggested are useful to overcome the unemployment gap, but they are insufficient. It is necessary to insert them into a Quantified Plan Technical and ideologically approved by Consensus (QPTIC) for the 2017-20 periode. It is not longer the time for make a simple list of new measures, but to estimate and calculate their effects in an integrated model.

Second: This model requires two prerequisites: to be SISTEMIC (the variables are interrelated) and AXIOLOGICAL (the "system of values" must be analyzed). Theoretically speaking would be highly disappointing to ignore these two prerequisites.

Third: From the axiological analysis should appear the three big unbalances which characterize the Spanish economy: the higher level of unemployment; many things to do for the satisfying of needs of people; and the country that waste more money. This fact is called "The Untenable Triad" and at the same time it is its better historic opportunity.

Forth: The Spanish unemployment level is due to its insufficient economic competitiveness, and given the "Untenable Triad" the solution is to create new jobs by both public and private means, centered in achieving two goals: a) to decrease the importation of oil; and b) to improve the natural environment. Both objectives imply the following investment plan: $1+D+1$ 
about electric batteries for cars; TICs development; more railway for transportations of goods and persons; more efforts on renewable energies; Building rehabilitations for energy savings; production of bio-energy from waste materials; more construction of byke-paths, among others. Table 2 shows more that 4 millions of possible new jobs during the 2017-20 periode.

Fifth: The financing of this plan is not at all a problem. There is enough monetary mass in circulation badly used. En millions of euros we have: Paid to unemployed, 20.000; decrease of fiscal fraud, 8.000; decrease of public expenses, 2000 (it would be possible to arrive to 15.000); participation of private enterprises 6000: In total 49.000 millions euros per year, or almost 200.000 in the 2017-20 period. Monetary mass enough to pays more than 2 millions jobs, investment included. Summarizing: The most probable result was: Unemployed in 2017: 3,914 millions, less 1,289 new jobs during the period of four years $=2,625$ as the new unemployed. Therefore 2,625/22,7 the active population $=11,6 \%$, or $12 \%$ in round figures, decrease of unemployment which is due only to the special effects of the model, and then complementary to the normal employment policy of the government.

Sixth: It will help the necessary Fiscal Reform from a systemic perspective, where the taxes on all the "productive" activities should be decreased, in the same level that the taxes to all the "consumptive" activities increased, so in order to leave fiscal effort unchanged.

Seventh: In parallel, other important reforms should be implemented like Education, Judicial system, Inspections, etc. that will help the implementation of the Plan and which are perfectly achievable.

Given the situation (October 2017) these seven actions should be prepared from this moment in order to be implemented since the very first day of the new government. And that taken advantage of the psychological impact that the CPTIC would have on the public opinion, both national and international. This is, due to the proved "Untenable triad" and other favorable factors, what the common sense is simply demanding to the new government. I wish the political responsible understand this demand. The problem is that the Spanish government, and even the Spanish people, does not care at all to see the unpresentable statistical figures of unemployment in journals like, f.i., The Economist.

\section{FOOTNOTES:}

1. See the presentation of the general contribution in F. Parra-Luna, "An Axiological Systems Theory: Some Basic Hypotheses", in Systems Research \& Behavioral Science, 00-2001.

2. The calculus of "efficiency" can be seen in F. Parra-Luna, "A Score Card for Ethical Decision Making", in Systems Research \& Behaviroral Science, 25, 2008.

3. An application to Political Science can be seen in F. Parra Luna "On the Social Sin of Political Analysis: A Critical Quantitative Approach from a Systemic Perspective" Systems Research and Behavioral Science, 30, 2013

4. The last works can be seen in: Equipo Multidis, Coord. F. Parra Luna y Jose I. Ruiz Rodriguez, "Para salir de la crisis: un modelo cuantitativo hacia la creación de empleo", Ed. del Serbal, Barcelona, 2010. Also in 
Parra Luna, F. "El paro permitido", Ed. Coronaborealis, Malaga, 2010. More recently in "Cuatro errores de la política económica en España”, Economistas, 128, 2011.

5. The relationship "need/value" was developed by C. Kluckhohn (1951) and it is in my opinion a seminal contribution to social sciences.

6. Doyal, L. y Gough, I, "Teoría de las necesidades humanas", Icaria, Barcelona, 1994.

7. Heller, A., "Teoria de las necesidades en Marx", Ed. Peninsula, Barcelona, 1978

8. Mendez, J.M., "Teoría del valor", Estudios de Axiología,Madrid, 1988.

9. Van Neff, M., "Desarrollo a escala humana: conceptos, aplicaciones y reflexiones", documento de trabajo, CEPAUR, Chile, 1993.

10. Ver p.e., F. Parra Luna, "Las organizaciones y sus sistemas de valores", Boletin de documentación del Fondo para la Investigación Economica y Social, Conf. Esp. De Cajas de Ahorros, vol IX, fasc. 3, JulioSeptiembre 1977. Y también "Axiological Systems Theory: Some Basic Hypotheses, Systems Research and Behavioral Science, 00. 1-26, 2001.

11. López Cossío, “La formación de los desempleados en España, Fundación Elogos, 2011.

BIBLIOGRAFIA (Complementaria)

Axelrod, Robert (1997): "Advancing the Art of Simulation in the Social Sciences", Complexity, 3, pp. 16-22.

Beinhocker, Eric (2006): The Origin of Wealth, Random House.

Benda, J.(2007): The treason of the intellectuals, Internet.

Bunge, M. (1980): Epistemología. Ciencia de la ciencia, Barcelona, Ariel.

Cabrillo Fernández, F.(2008): Liberalismo y liberalismos, LibertadDigital.com.

Groom B.(2008): A fragile flexibility, Financial Times, 14 Abril.

Durlauf, S.N.(1997): What should policymakers know about Economic Complexity?, wp

97-10-080, Santa Fe Institute.

Hougthon, L.(2008): "Generalization and Systemic Epistemology; Why should it Make Sense?", Systems Research and Behavioral Science, 26-10.

Kluckhohn, C.(1951): "Los valores y las orientaciones de valor en la teoría de la acción", en Parsons T. and Shils, E. Teoría de la Acción Social, F. Press.

Nechansky H.(2009): «Elements of Cybernetic Epistemology: Desing Rules for Complex Goal-Oriented Systems», Systems Research and Behavioral Science, vol. $26,4-8$.

Parra Luna, F.(2001): "An Axiological Systems Theory: Some Basic Hypotheses", Systems Research and Behavioral Sciences, 18.

Pavard, B. y Dugdale, J.(2000): "The contribution of complexity theory to the study of socio-technical Systems", New England Complex Systems Institute electronic journal.

Pulido San Román A. y Pérez García, J.(2001): Modelos Econométricos, Madrid, Pirámide.

Requeijo, J. (2009): Odisea 2050: La economía mundial del siglo XXI, Madrid, Alianza. 